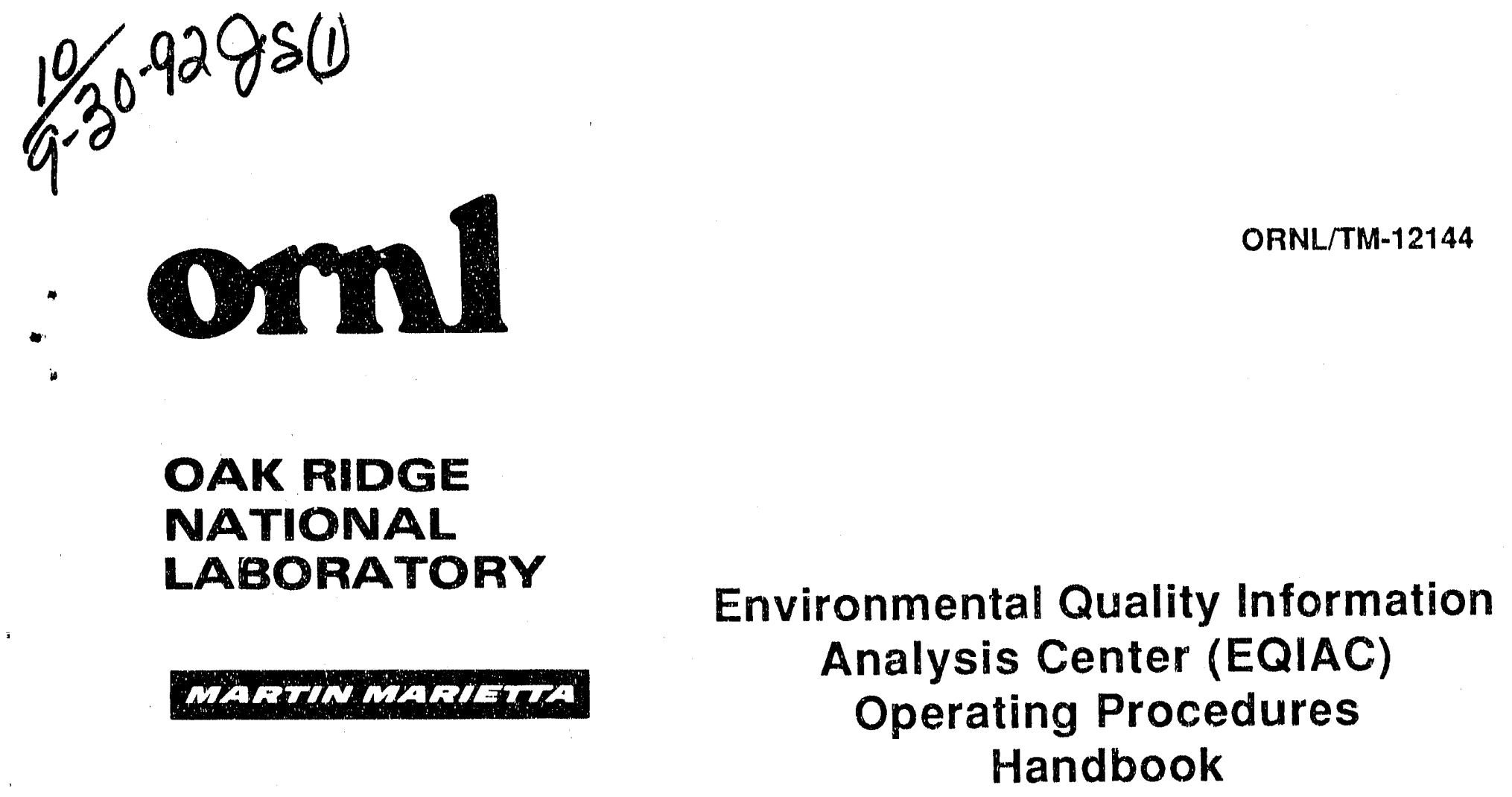

Thomas E. Walsh

Sujit Das 
This report has been reproduced directly from the best available copy.

Available to DOE and DOE contractors from the Office of Scientific and Technical Information, P.O. Box 62, Oak Ridgo, TN 37831; prices avaliable from (615) 676-8401, FTS 626-8.401.

Available to the public from the National Technical Information Service, U.S. Department of Commerce, 5285 Port Royai Rd., Springfield, VA 22161.

This report was prepared as an account of work sponsored by an agency of the United States Government. Neither the United States Government nor any agency thereof, nor any of their employees, makes any warranty, express or implied, or assumes any legal llability or responsibility for the accuracy, completeness, or usefulness of any information, apparatus, product, or process disclosed, or represents that its use would not infringe privately owned rights. Reference herein to any specific commercial product, process, or service by trade name, trademark, manufacturer, or otherwise, does not necessarily constitute or imply its endorsement, recommendation, or favoring by the United States Government or any agency thereof. The views and opinions of authors expressed herein do not necessarily state or reflect those of the United States Government or any agency thereof. 


\title{
ENVIRONMENTAL QUALITY INFORMATION ANALYSIS CENTER (EQIAC) OPERATING PROCEDURES HANDBOOK
}

\author{
Thomas E. Walsh* \\ Sujit Das*" \\ "University of Florida, Gainesville, Fla. \\ "Oak Ridge National Laboratory, Oak Ridge, Tenn.
}

August 1992

Prepared for the

U.S. Air Force

Air Force Civil Engineering Support Agency

Tyndall Air Force Base, Florida

Prepared by the

OAK RIDGE NATIONAL IABORATORY

Oak Ridge, Tennessee 37831

managed by

MARTTN MARIETTA ENERGY SYSTEMS, INC.

for the

U.S. DEPARTMENT OF ENERGY

under contract DE-AC05-84OR21400 
1. INTRDDUCTION $\ldots \ldots \ldots \ldots \ldots \ldots \ldots \ldots \ldots \ldots \ldots \ldots \ldots \ldots \ldots \ldots \ldots$

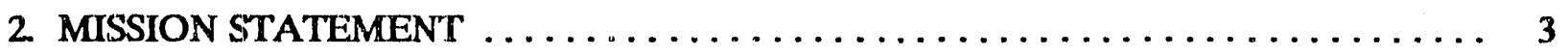

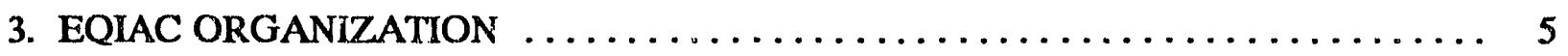

4. EQIAC PROGRAM MANAGER $\ldots \ldots \ldots \ldots \ldots \ldots \ldots \ldots \ldots \ldots \ldots \ldots \ldots \ldots$

5. OFFICE OF THE DIRECTOR $\ldots \ldots \ldots \ldots \ldots \ldots \ldots \ldots \ldots \ldots \ldots \ldots \ldots \ldots$

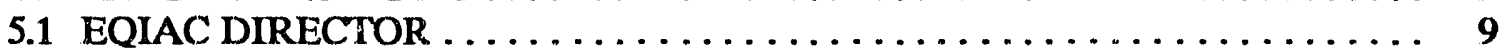

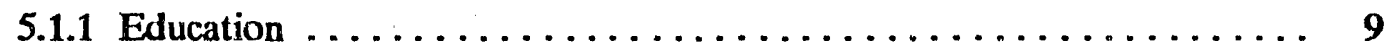

5.1.2 Training and Experience ..................... 9

5.1 .3 Duties and Responsibilities ..................... 9

5.2 ADMINISTRATIVE/CLERICAL (EXECUTTVE) ASSISTANT TO THE

DIRECTOR .......................... 9

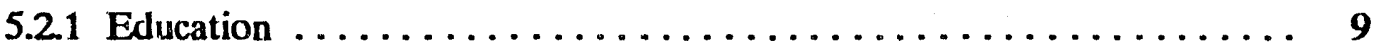

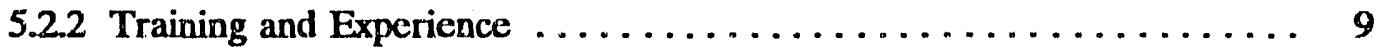

5.23 Duties and Responsibilities ................... 9

5.3 ADMINISTRATIVE/CLERICAL ASSISTANT (TWO) $\ldots \ldots \ldots \ldots \ldots \ldots \ldots$

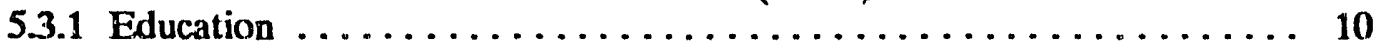

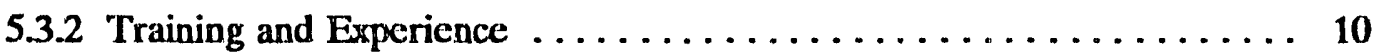

5.3 .3 Duties and Responsibilities ..................... 10

5.4 COMPUTER AND COMMUNICATIONS SPECIALIST $\ldots \ldots \ldots \ldots \ldots \ldots \ldots$

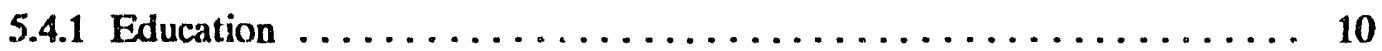

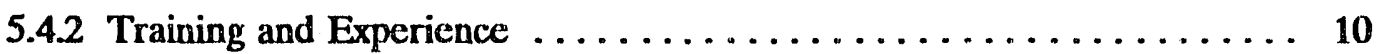

5.4 .3 Duties and Responsibilitics ................... 10

5.5 CONFERENCE AND TECHNOLOGY TRANSFER SPECIALIST $\ldots \ldots \ldots 11$

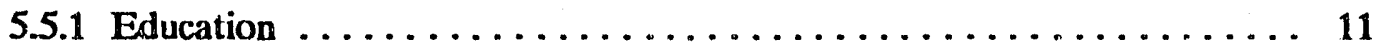

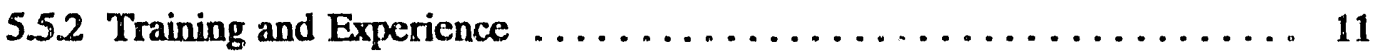

5.5 .3 Duties and Responsibilities .................. 11

6. ANALYTICAL SERVICES $\ldots \ldots \ldots \ldots \ldots \ldots \ldots \ldots \ldots \ldots \ldots \ldots \ldots \ldots \ldots$

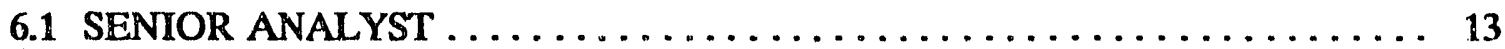

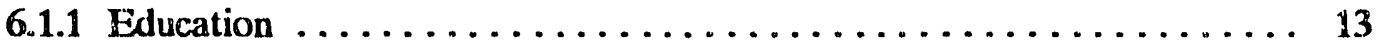

6.1.2 Training and Experience $\ldots \ldots \ldots \ldots \ldots \ldots \ldots \ldots \ldots \ldots \ldots \ldots \ldots$

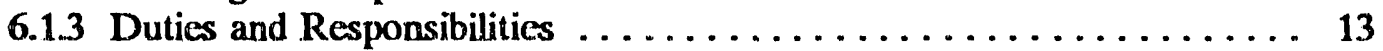

6.2 TECHNICAL ANALXSTS (NINE) $\ldots \ldots \ldots \ldots \ldots \ldots \ldots \ldots \ldots \ldots \ldots \ldots$

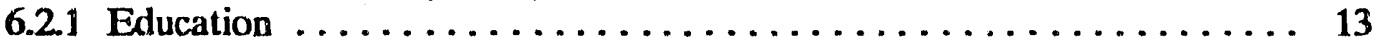

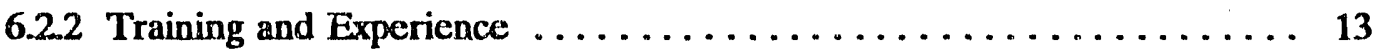

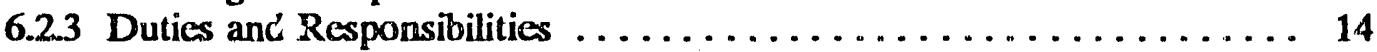

6.3 CONSULTANTS $\ldots \ldots \ldots \ldots \ldots \ldots \ldots \ldots \ldots \ldots \ldots \ldots \ldots \ldots \ldots \ldots \ldots$ 


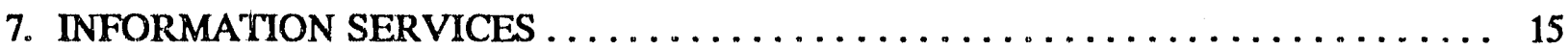

7.1 SENIOR INFORMATION SPECIALIST $\ldots \ldots \ldots \ldots \ldots \ldots \ldots \ldots \ldots, 15$

7.1.1 Education $\ldots \ldots \ldots \ldots \ldots \ldots \ldots \ldots \ldots \ldots \ldots \ldots \ldots \ldots \ldots, 15$

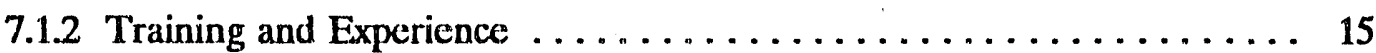

7.1.3 Duties and Responsibilities .......................... 15

7.2 INFORMATION SPECIALISTS (FOUR) $\ldots \ldots \ldots \ldots \ldots \ldots \ldots \ldots \ldots \ldots \ldots \ldots$

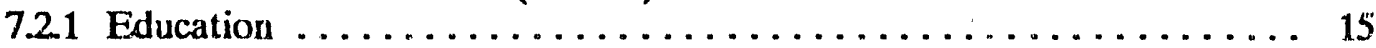

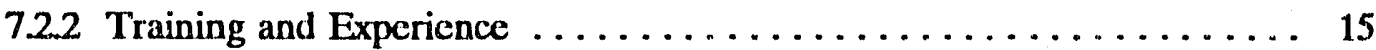

7.2.3 Duties and Responsibilities . . . . . . . . . . . . . . . . 16

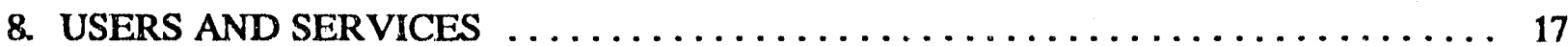

8.1 CLASSES OF USERS $\ldots \ldots \ldots \ldots \ldots \ldots \ldots \ldots \ldots \ldots \ldots \ldots \ldots \ldots \ldots \ldots \ldots \ldots, 17$

8.2 CLASSES OF SERVICES $\ldots \ldots \ldots \ldots \ldots \ldots \ldots \ldots \ldots \ldots \ldots \ldots \ldots \ldots \ldots \ldots \ldots \ldots, 17$

8.2.1 Scientific/Technical Services $\ldots \ldots \ldots \ldots \ldots \ldots \ldots \ldots \ldots \ldots \ldots \ldots$

8.2.1.1 Data Accession and Collection ................ 17

8.21.2 Bibliographic Inquiry Responses $\ldots \ldots \ldots \ldots \ldots \ldots \ldots, 18$

8.21 .3 Technical Inquiry Responses ................. 18

8.2.1.4 Technology Assessments And Critical Revicws ......... 18

8.2.1.5 Models ................................. 19

8.2.2 Planning/Programmatic Services $\ldots \ldots \ldots \ldots \ldots \ldots \ldots \ldots \ldots \ldots \ldots$

8.2.2.1 Models ........................... 19

8.2.2.2 Special Studies and Tasks ................... 19

8.2.3 Technology/Information Transfer Services ................. 19

8.2.3.1 EQIAC Update (Newsletter) $\ldots \ldots \ldots \ldots \ldots \ldots \ldots \ldots \ldots$

8.2.3.2 Handbooks and Data Books .................. 20

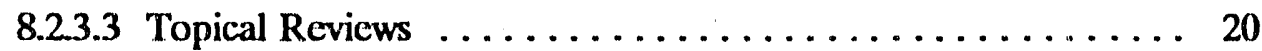

8.2.3.4 Training Courses and Seminars $\ldots \ldots \ldots \ldots \ldots \ldots \ldots, 20$

8.2.3.5 Data Base Activity Coordination $\ldots \ldots \ldots \ldots \ldots \ldots \ldots 20$

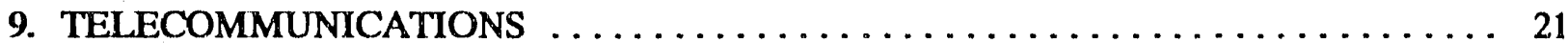

9.1 SYSTEM DESCRIPTION $\ldots \ldots \ldots \ldots \ldots \ldots \ldots \ldots \ldots \ldots \ldots \ldots \ldots \ldots \ldots \ldots \ldots \ldots, 21$

9.2 INFORMATION SOURCES $\ldots \ldots \ldots \ldots \ldots \ldots \ldots \ldots \ldots \ldots \ldots \ldots \ldots \ldots \ldots$

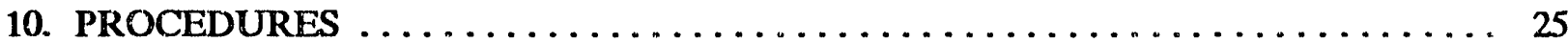

10.1 REVISIONS AND UPDATES OF PROCEDURES $\ldots \ldots \ldots \ldots \ldots \ldots \ldots, 25$

10.2 BUDGETING AND FISCAL PLANNING $\ldots \ldots \ldots \ldots \ldots \ldots \ldots \ldots \ldots, 25$

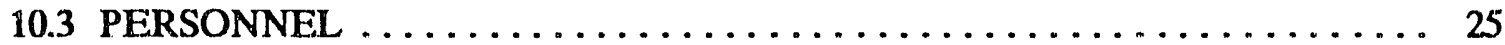

10.4 USER INQUIRY FOR SCIENTIFIC/TECHNICAL SERVICES $\ldots \ldots \ldots \ldots 25$

10.4.1 User Inquiry Records $\ldots \ldots \ldots \ldots \ldots \ldots \ldots \ldots \ldots \ldots \ldots \ldots \ldots \ldots \ldots \ldots, 25$

10.4.2 Quality Control of User Inquiry Respunses $\ldots \ldots \ldots \ldots \ldots \ldots \ldots 26$

10.4.3 Charges for Scientific/Technical Services ................. 26

10.4.4 Internal Requests for Scientific/Technical Services ............ 26

10.5 USER REQUESTS FOR PLANNING/PROGRAMMATIC SERVICES $\ldots \ldots 26$

10.5.1 Quality Control of Planning/Programmatic Services ........... 27

10.5.2 Charges for Planning/Programmatic Services ............. 27 
10.6 TECHNOLOGY/INFORMATION TRANSFER SERVICES $\ldots \ldots \ldots \ldots \ldots 27$

10.6.1 Scheduling of Technology//nformation Transfer Services . . . . . . . 27

10.6.2 Charges for Technology/Information Transfer Services . . . . . . . . . 27

10.6.3 Quality Control of Technology Transfer/Information Services . . . . 28

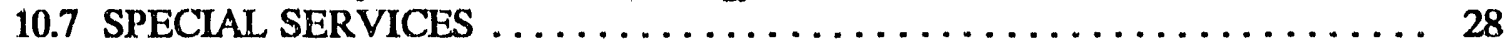

10.7.1 Requests for Special Services .................. 28

10.7.2 Quality Control of Special Services . . . . . . . . . . . . 29

APPENDIX A: A PRELIMINARY LIST OF INFORMATION ANALYSIS CENTERS THAT ARE USEFUL TO ENVIRONMENTAL QUALITY INFORMATION ANALYSIS CENTER.

APPENDIX B: A PRELIMINARY LIST OF BIBLIOGRAPHIC DATA BASES RELATED TO ENVIRONMENTAL TECHNOLOGIES.

APPENDIX C: EQIAC PROCEDURE FORMS 


\section{LIST OF FIGURES}

3.1 Organizational Chart (Full Operational Capability) $\ldots \ldots \ldots \ldots \ldots \ldots \ldots \ldots \ldots$

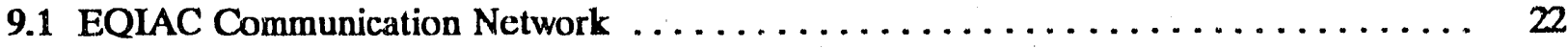




\section{INTRODUCTION}

The Operating Procedures Handbook of the Environmental Quality Information Analysis Center (EQIAC) is intended to be kept current as EQLAC develops and evolves. Its purpose is to provide a comprehensive guide to the mission, infrastructure, functions, and operational procedures of EQIAC. The handbook is a training tool for new personnel and a reference manual for existing personnel. The handbook will be distributed throughout EQIAC and maintained in binders containing current dated editions of the individual sections. The handbook will be revised at least annually to reflect the current structure and operational procedures of EQIAC.

This initial version, dated July 1992, describes EQIAC in the projected Full Operational Capability (FOC) mode. This mode may not be achieved for up to two years. The Initial Operational Capability (IOC) may be achieved by the fourth quarter of 1992 with a cadre of personnel who will become the supervisory heads of the subgroups of EQIAC described in this handbook. 


\section{MISSION STATEMENT}

EQIAC is established under the authority of the Air Force Civil Engineering Support Agency (AFCESA), Tyndall Air Force Base, Florida. EQIAC is operated as a unit within AFCESA/Research and Acquisition with funding from AFCESA, other Air Force and Department of Defense (DoD) Services, and the U.S. Department of Energy (DOE).

The mission of EQIAC is to assist civil and environmental engineers and technicians, planners, technologists, researchers, and decision makers by providing scientific and technical information on environmental issues that either remain to be or are inadequately addressed. To accomplish its mission, EQIAC gathers, validates, evaluates, and disseminates data and information on site restoration, pollution prevention, and compliance issues to the Air Force and DoD community and their contractors. The specific subjects included within these areas are bioremediation, physical and chemical remediation, site characterization and monitoring, hazardous waste minimization, atmospheric fate and transport, airborne toxic emissions, subsurface fate and transport, risk assessment, and scientific technical and cost evaluation modeling. A systems approach to characterizing and analyzing the problem is used to optimize a particular solution and to understand fully the conditions for applying that solution at other sites. EQIAC products and services fall within three realms: scientific and technical services, planning and programmatic services, and technology transfer initiatives.

EQIAC provides critical reviews and assessments of new and developing technologies and scientific findings as well as evaluations of their suitability to particular applications. The major focus of EQIAC is to provide or help develop technical solutions to an environmental problem, to facilitate technology transfer to industry, and to recommend new research ventures. Programmatic assessments, assessment of off-the-shelf technology alternatives, and development of investment strategies are a few of the planning and programmatic services to be offered by EQIAC. Workshops, scientific and technical exchanges, and conferences are conducted as one of the methods of promoting technology development and transfer.

EQIAC acquires necessary technical data and models from a network of cooperating information centers and repositories of data and models without duplicating the functions or holdings of those centers and repositories. Reviews and assessments of techrologies, and the models and tools developed to produce them, are the principal holdings of EQIAC. The secondary holdings of EQIAC are data from the external cooperating network of centers and repositories that EQIAC has analyzed and found especially accurate and useful to its mission. These filtered data are made available to the cooperating cisnters and to technologists for their use. By these actions, the goal of improving the availability of quality of environmental information to users and identifying or facilitating the filling of voids in ex sting data or knowledge bases in an economical, efficient, and unbiased manner is achieved.

The ir itial emphasis of EQIAC is on further development of the Air Force's Environmental Quality Rese arch and Acquisition Strategic Plan. EQIAC services are provided to authorized sponsors outside the Air Force on a limited basis during the phase-in period. These initial capabilities (to be in place by the fourth quarter of 1992) will be supplemented over a phase-in period to provide services to limited users beyond the Air Force. FOC for EQIAC should be achieved no later than December 1994. Other DoD services and agencies and DOE have needs similar to those of the Air Force, and EQIAC services are made available to them through interagency funding transfers for blocks of service support. Service to other types of sponsors is considered on a case-by-case basis with the condition that these services do not interfere with the primary mission of EQIAC. 


\section{EQIAC ORGANIZATION}

The EQIAC organizational chart, as shown in Fig. 3.1, follows the matrix-management organizational approach, wherein the two major sections of EQIAC (Analytical Services headed by the Senior Analyst and Information Services headed by the Senior Information. Specialist) handle EQIAC products and services. For any EQIAC service, the team is formed from the personnel of these two major sections, where the mix of personnel depends on the type of service to be provided. These two major sections are at the same level of hierarchy responsibility, and overall direction is provided to them by the Director. The Program Manager is responsible for the overall management of EQIAC and its support staff. A detailed description consisting of education, training and experience, and duties and responsibilities for each EQIAC team member is provided in Sects. 4 - 7. Training and field experience (not education) are to be given the foremost consideration in the selection of an EQIAC team member. Education requirements are to be relaxed at the expense of availability of better trained and experienced personnel. 


\section{Program Manager \\ Director

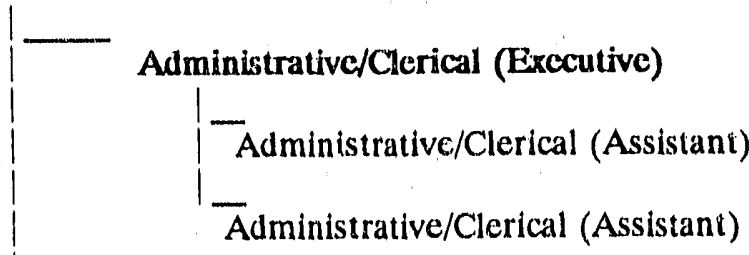

Computer and Communications Specialist

Conference and Technology Transfer Specialist

Senior Analyst [Analytical Servicus]

Analyst/Technical (Hazard Minimization/Remediation Biotechnology)

Analyst/Technical (Remediation Physical/Chemical)

Analyst/Technical (Industrial Operations)

- Analyst/Technical (Hazard Minimization Technologies)

Analyst/Technical (Compliance, Water, and Air)

- Analyst/Terinical (Remediation Physical/Chemical Or Biotechnology)

Analyst/Technical (Economic)

Analyst/Technical (Modeling)

Analyst/Technical (Data Exchange/Technology Transfer)

Consultants

Senior Information Specialist [Information Services]

Information Specialist

Information Specialist

Information Specialist

Information Specialist

Fig. 3.1 Organizational Chart (Full Operational Capability) 


\section{EQIAC PROGRAM MANAGER}

The guidelines delineated in this section will be used in selecting the EQIAC Program Manager.

\subsection{EDUCATION}

The successful candidate for Program Manager should have at least one graduate level physical science, life science, or engineering degree relevant to environmental studies.

\subsection{TRAINING AND EXPERIENCE}

The EQIAC Program Manager should have at least 10 years of proven experience in environmental research and development; familiarity with Air Force environmental needs, and successful program management experience involving contract administration, planning, and budgeting.

\subsection{DUTIES AND RESPONSIBILITIES}

The EQIAC Program Manager will be responsible for the overall management, oversight, and direction of EQIAC activities and EQIAC support staff. This individual will provide programmatic direction and promote EQIAC throughout the Air Force and DoD, authorize tasking from a program management standpoint subject to contracting authority, and provide the annual evaluation of the EQIAC Director. 
ORNL/TM-12144

8 


\section{OFFICE OF THE DIRECTOR}

\subsection{EQIAC DIRECTOR}

The EQIAC Director should meet the requirements established in this section.

\subsubsection{Education}

The successful candidate for the EQIAC directorship should possess a doctorate in the physical or life sciences or engineering relevant to environmental studies.

\subsubsection{Training and Experience}

The EQIAC Director must be a proven leader with at least 15 years of extensive experience in environmental operations, including research and development and familiarity with Air Force enviionmental needs. This individual must also have a successful track record of exceptionally strong marketing skills and demonstrated leadership skills in management roles that require planning, budgeting, and personnel selection and supervision.

\subsubsection{Duties and Responsibilities}

The Director will be responsible for the overall direction of EQIAC and its personnel to achieve its stated mission.

\subsection{ADMINISTRATTVE/CLERICAL (EXECUTTVE) ASSISTANT TO THE DIRECTOR}

The following guidelines will be used in selecting the Administrative/Clerical (Executive) Assistant to the Director.

\subsection{Education}

The successful candidate for Executive Assistant to the Director should have a minimum of secondary education or certification, preferably bachelor's degree in business or administration.

\subsection{Training and Experience}

The Executive Assistant should have at least five years experience in administrative and clerical support and demonstrated ability to work independently given broad guidance in positions requiring good communications skills.

\subsubsection{Duties and Responsibilities}

The Executive Assistant will provide administrative and clerical support to the Director, maintain awareness of the overall distribution of duties within EQIAC staff, and provide routing of inquiries to the appropriate section within EQIAC. 


\subsection{ADMINISTRATTVE/CLERICAL ASSISTANT (TWO)}

Successful candidates for Administrative/Clerical Assistant will possess the following qualifications.

\subsubsection{Education}

The candidates should possess a minimum of secondary education, with preference given for undergraduate degree.

\subsubsection{Training and Experience}

Administrative/Clerical Assistants should show at least five years of proven clerical or administrative experience with the ability to work independently.

\subsubsection{Duties and Responsibilities}

The Administrative/Clerical Assistants will provide administrative and clerical support to the Director and other staff members of the section.

\subsection{COMPUTER AND COMMUNICATIONS SPECIALIST}

The following guidelines will determine a successful candidate for Computer and Communications Specialist.

\subsubsection{Education}

The successful candidate will possess an undergraduate degree or equivalent in computer science or engineering.

\subsubsection{Training and Experience}

The Computer and Communications Specialist should have five years experience with hardware and software relevant to the telecommunications needs described in Sect. 9, emphasizing proven ability to modify and expand local area networks to accommodate growing EQIAC responsibilities.

\subsubsection{Duties and Responsibilities}

The Computer and Communications Specialist will provide the Director with timely information regarding the maintenance, operation, and future expansion of the computing and telecommunications resources of EQIAC and will be responsible for daily availability of computing and telecommunication services to meet the needs of EQIAC staff. 


\subsection{CONFERENCE AND TECHNOLOGY TRANSFER SPECIAIIST}

The Conference and Technology Transfer Specialist should meet the following requirements.

\subsubsection{Education}

The successful candidate will hold an undergraduate degree or equivalent in engineering, physical sciences, or business administration.

\subsubsection{Training and Experience}

The successful candidate will possess 10 years of proven experience in transfer of technology from research and development (R\&D) laboratories to field applications. Further, he or she must have a successful track record of plannirg and conducting of workshops, conferences, and cooperative R\&D agreements as vehicles for technology transfer.

\subsubsection{Duties and Responsibilities}

The Conference and Technology Transfer Specialist is responsible for coordinating efforts of EQIAC staff and external organizations in conducting workshops and conferences on environmental topics of emerging interest. Further responsibilities include assisting in the establishment of cooperative R\&D programs and data base/technical information activities with EQIAC users and sources. 


\section{ANALYTICAL SERVICES}

\subsection{SENIOR ANALYST}

The Senior Analyst should meet the requirements established in this section.

\subsubsection{Education}

The sc -cessful candidate for Senior Analyst should possess a doctoral degree in physical or life sciences, or engineering relevant to environmental studies.

\subsubsection{Training and Experience}

The Senior Analyst must have at least 10 years experience in positions of increasing technical and management responsibility; proven experience in environmental operations, prelierably including research and development experience; and recognized record of supervisory management skills and demonstrated ability to conduct concurrent projects and apportion human resources against a changing workload.

\subsubsection{Duties and Responsibilities}

Responsibilities of the Senior Analyst include leadership of the Analytical Services Section in performing modeling, analysis, and technical evaluation; apportionment of the analytical staff against an array of tasks; support effort of the Director in executing tasking for sponsors and originating proposals for future work. The Senior Analyst will also provide quality control for products of the technical analysts within the Analytical Services Section and for all EQIAC responses to user inquiries, including those made to Information Services.

\subsection{TECHNICAL ANALYSTS (NINE)}

Successful candidates for Technical Analyst will meet the following guidelines.

\subsubsection{Education}

Technical Analysts should possess a minimum of graduate degree (Doctoral degree or Masters degree with additional experience) in the appropriate disciplines: engineering, physical or life sciences, economics, or business administration.

\subsubsection{Training and Experience}

Successful applicants will have a minimum of five years experience for Doctoral degree or seven years experience for Masters degree in positions relevant to the following topics (Hazardous Materials Minimization, Biotechnology Remediation, Physical/Chemical Remediation, Industrial Operations 
Modifications, Compliance: Water and Air, Requirements/Alternatives, Economics, Modeling, Data Exchange, or Technology Transfer). Further, successful applicants must have demonstrated ability to work independently meeting deadlines.

\subsubsection{Duties and Responsibilities}

Under the direction of the Senior Analyst, Technical Analysts are responsible for performing technical analyses in support of users, providing recommendations to the Senior Analyst for improvements in EQIAC analytical resources, and identifying future needs for support from the Information Services Secticn.

\subsection{CONSULTANTS}

A roster of external consultants will be available to support EQIAC support staff under the Supplemental Support Group (surge capability). Requirements must be specific to ensure that nationally- and internationally-recognized experts are provided as consulting staff. Consultants must be capable of rapid response to special tasks or inquiries and should be thoroughly familiar with EQIAC function as well as with EQIAC analytical staff members. The Program Manager will be responsible for the performance of external consultants. 


\section{INFORMATION SERVICES}

\subsection{SENIOR INFORMATION SPECIALIST}

The Senior Information Specialist should meet the following requirements.

\subsubsection{Education}

Successful candidates for Senior Information Specialist should hold a graduate degree in information sciences or library sciences.

\subsubsection{Training and Experience}

The Senior Information Specialist should have at least 10 years experience in technical information retrieval in the physical, biological, or preferably environmental sciences area, with proven expertise in utilization of modern electronic data base services, as well as demonstrated ability to supervise personnel and to plan for resource needs and allocation of those resources. Experience in managing human resources, as well as hardware and software resources, is necessary.

\subsubsection{Duties and Responsibilities}

Responsibilities of the Senior Information Specialist will include leadership of the Information Services Section in providing information support to the Analytical Services Section, the Marketing Section, and external users. Responsibilities also include apportionment of the Information Services staff against an array of tasks, planning for information resource needs, and providing quality control for products produced by information specialists within the Information Services Section.

\subsection{INFORMATION SPECIALISTS (FOUR)}

Successful candidates for Information Specialist should possess the following qualities.

\subsubsection{Education}

An undergraduate degree in library or information sciences is required, but a graduate degree is preferred.

\subsection{Training and Experience}

Information Specialist candidates should demonstrate at least five years experience in technical information retrieval in the physical, biological, or preferably environmental sciences area, with proven expertise in utilization of modern electronic data base services. At least one of the information specialists should have proven experience in publication of technical awareness bulletins and newsletters. 


\subsubsection{Duties and Responsibilities}

Under the direction of the Senior Information Specialist, Information Specialists will perform information searches in support of Analytical Services and external users; provide recommendations to the Senior Information Specialist for improvements in EQIAC information retrieval services; and work at multiple tasks in support of various project teams from the Analytical Services Section. 


\section{USERS AND SERVICES}

\section{CAASSES $~ F$ G USERS}

The two principal classes of EQIAC users are planners and technologists. Planners include those who plan programs of Research, Development, and Acquisition, as well as those wno plan projects of site remediation, pollution prevention, or environmental compliance. Technologists include berich-level scientists, technical project managers, remediation project managers, site engineers, and depot production engineers.

Subclasses of users based on the organizational affiliation of the user are the Air Force, other Service or DoD agency, other federal agencies [especially DOE and Environmental Protection Agency (EPA)], and industry, academia, and foreign government entities [e.g. North Allantic Treaty Organization (NATO) cooperative programs].

Users are further differentiated by the mechanism of EQIAC funding by the user"s organization. Primary sponsor organizations are those who have transferred funds to support the ongoing EQIAC activity. Cooperating sponsors are those who contribute either personnel or services in support of EQIAC. Ad-hnc sponsors are those funding a special study and task, or a workshop on a one-time basis (although the same organization may fund a series of such special tasks).

Authorized users may come from any of the above classes and subclasses. Their designation as authorized derives from approval from the EQIAC Program Manager and the cognizant contract officer.

Complimentary services such as bibliographic and technical inquiry responses may occasionally be provided to individuals who are not authorized users, upon special approval from the Program Manager.

\subsection{CLASSES OF SERVICES}

EQIAC provides three classes of services: Scientific/Technical (analytical/informational) services, Planning/Programmatic services, and Technology Transfer services (conferences, topical workshops, etc.).

\subsubsection{Scientific/Technical Services}

\subsubsection{Data Accession and Collection}

The Information Services Section of EQIAC, through its arrangements with a network of cooperating centers, and through its own holdings, provides technical data to authorized users and to the Analytical Services Section of EQIAC. The Information Services Section accesses such technical data and evaluates it for accuracy and reliability. Voids in existing technical data are either identified and remedied using EQIAC resources or recommended as candidates for supplemental funding from authorized users to remedy the deficiency. 
The analyzed data are delivered to users, and those data of particular quality and utility are indexed for future retrieval. To every degree possible, only the indices are stored, with original data retained at the cooperating centers.

\subsubsection{Bibliographic Inquiry Responses}

The EQ'AC Information Services Section will support requests from authorized users for bibliographic searches and compilations. There is no unit charge for this service to authorized users, whose authorization derives in part from their institutional funding of EQIAC. On-line services may be provided in exceptional cases. Information specialists within the Information Services staff receive telephone or electronic transmission of bibliographic inquiries, perform searches, and deliver results electronically or by mail to authorized requestors.

\subsubsection{Technical Inquiry Responses}

Responses to requests for technical information (other than bibliographic) are provided to authorized users by the Information Services Section. These responses may take the form of referrals to other centers in the network of cooperating centers, compilations of recommended technical approaches derived from previous studies performed by Analytical Services, or recommendations of key technical personnel in the environmental community who may provide assistance to the requestor.

Primary responsibility for directing external inquiries to appropriate staff within EQIAC is assigned to the Senior Information Specialist, supported by the other Information Specialists, to provide continuous coverage of external inquiries. Responsibility for acknowledgement of the assignment and preparation of the response rests with the individual Technical Analyst, Information Specialist, or both, depending on the request's routing. An individual Technical A nalyst or Information Specialist is identified to coordinate the preparation of each response. Identification of these coordinators is the joint responsibility of the Senior Analyst and the Senior Information Specialist. The log of these lead individuals assigned to the inquiries, as well as the record of the content of responses, is maintained only by the Senior Information Specialist.

\subsubsection{Technology Assessments And Critical Reviews}

The Analytical Services Section of EQIAC provides support to sponsoring planning offices in analyzing available off-the-shelf technology to determine its applicability to the planning problem at hand. In performing this function, Analytical Services Section draws upon the data contained in the network of cooperating centers and EQIAC's own data base. Models from EQIAC and the network are also provided to planners.

When the analysis of available technology indicates inadequacy to meet current needs, surveys and workshops are recommended to planners as a quick-reaction method of examining new technical approaches for consideration by planners. When such workshops appear to be warranted to planners, the Conference Specialist conducts the workshop using participants from EQIAC staff, EQIAC's roster of external consultants, and ad-hoc panels of world class experts. The results of their synthesized findings are then provided to planners in support of their mission. Workshops and topical reviews without temporal urgency are usually performed by the Information Services Section. In cases where extended assessments are warranted to meet current needs, funding or research support is solicited from the sponsor having that critical need. 
State-of-the-art critical reviews are generated by the EQIAC Information Services Section based on the perception of the emerging needs of the planning community, rather than in response to specific task requests from sponsors. These reviews are conducted on a longer time scale that does not interfere with the quick-response capability of EQIAC. The reviews are made available to planners and technologists; they may also serve as a marketing tool for extending knowledge of EQIAC capabilities to a wider range of potential users.

\subsubsection{Models}

Models are also used in providing scientific and technical services of EQIAC and for obtaining information such as identification and support for R\&D/technology needs. The models used are either generated by Analytical Services staff or drawn using models from the network of cooperating centers.

\subsubsection{Planning/Programmatic Services}

\subsubsection{Models}

Analytical Services staff generate models as well as draw models from the network of cooperating centers for providing planning services. These models are used in performing specific planning/programmatic tasks and are made available in support of technology assessments and critical reviews. The models are made available to planners and technologists along with technical advice and training in their use, provided that this service neither interferes with, nor detracts from, the main mission of EQIAC.

\subsubsection{Special Studies and Tasks}

Special studies and tasks are services provided to authorized users other than the primary sponsors of EQIAC. These ad-hoc services are conducted on a case-by-case basis when they enhance the EQIAC mission. Usually performed in a rapid response mode, they consist of modeling, development of models, technology assessments, or critical reviews. Special studies and tasks include support to Technology Demonstration Projects either in the planning stage or during the demonstration. The results of such tasks add to the lessons-learned data base of EQIAC.

\subsubsection{Technology/Information Transfer Services}

\subsubsection{EQIAC Update (Newsletter)}

The EQIAC newsletter provides to the user community technical awareness of EQIAC'S activities and concise highlights of significant events in the lield of environmental quality information. Newsletter contents generally include the following topics:

- Synopses and critiques of important new literature

- New technology programs and technical report overviews

- Announcements of future meetings, forums, and conferences

- Technical breakthroughs and nev applications

- Announcements of EQIAC products and services 
Information for laypersons interested in enhancement and management of the environment

\subsubsection{Handbooks and Data Books}

Handbooks and data books are published as warranted based on accumulation of results from analytical studies or based on community interest in specialized topics. Compilations of models, or of bibliographies on topics of considerable community interest, are made available without charge to EQIAC sponsors and are distributed on a cost recovery basis to interested external parties.

\subsection{3; Topical Reviews}

Topical reviews are workshops that do not have a time-urgent user-driven need for the results of the workshop. Topics of emerging interest to the environmental quality community are identified and conducted in one of two modes. The low-cost mode is a supplemental session to a scheduled major technical or programmatic meeting; in this case, EQIAC serves somewhat as a catalyst, maximizing the output fiom the available participants. The higher cost mode is a stand-alone topical review, usually supported by funding supplements from user groups interested in the coherence that such a community effort can provide when conducted by a recognized source of quality information such as EQIAC.

\subsubsection{Training Courses and Serninars}

Training is provided to users in accessing EQIAC services and in using EQIAC products. Coordination with other cooperating centers in the network is achieved through jointly sponsored seminars on topics of mutual interest, especially on cooperative data base development and interconnectivity. Conference support is provided to EQIAC sponsors as an effective means of information transfer.

\subsubsection{Data Base Activity Coordination}

Data base activities of other sources are coordinated by providing a single point source for environmental quality information. EQIAC provides its users the knowledge about the types, formats, quantity, and quality of information for all the information sources serving environmental quality.

With working knowledge of various information sources, EQIAC would also serve as a mediator/facilitator in establishments of information focal points. Information sources with limited holdings in a given topic area would transfer their holdings to an information focal point (having far more holdings in the same topic area). These information focal points gain by getting higher volumes of information and service requests, and subsequently may become Information Analysis Centers for their given topic areas. Formation of information focal points will facilitate increased use of many of the existing information sources and will improve access, quality, and quantity of information available to environmental quality information users. 


\section{TELECOMMUNICATIONS}

\subsection{SYSTEM DESCRIPTION}

EQIAC will develop as a stand-alone organization within the AFCESA. Resources exist [i.e., the Technical Information Center (TIC) and computational facilities] $]^{1}$ within the AFCESA that will be useful during the periods of its IOC and phase-in to FOC. The EQIAC telecommunication network will operate independently within the AFCESA, communicating with TIC resources in a way similar to other IACs,

Figure 9.1 shows the communication network for EQIAC in the projected FOC mode. The EQIAC communication network consists of a Local Area Network (LAN), which is an ethernet, having a backbone topology and using TCP/IP as the protocol. The hardware platform (a RISCbased UNIX processor with $256 \mathrm{MB}$ RAM) connecting to the LAN serves as ethernet and e-mail serve's, as well as file servers for personal computer (PC) terminals and workstations. In addition, the on-line bibliographic software (i.e., BASIS/TECHLIB+) for cataloguing EQIAC's holdings, products, services, and computational requirements by the technical analysts is provided by the hardware platform.

The peripheral devices, such as printers, are connected to the LAN. A total of four printers are shared among all EQIAC team members. Each Information Specialist is provided with a workstation (80486-based PC with at least 4 Megabytes (MB) of memory) and a combination facsimile machine (facsimile machine, scanner, and printer) to send and receive documents directly. Each Technical Analyst also has a workstation, but five combination facsimile machines are shared among ten of them. Each of the two Technical Analysts involved in scientific/technical modeling, cost modeling, and economic analysis has a workstation with a higher memory of 32MB. The Program Manager, Director, and Clerical Assistants, each have a PC-terminal (80486-based PC with 640K of memory).

Communication between EQIAC and on-line data bases and other IACs is accomplished by means of direct dial-ups through modems. Modem server and modem stack with several phone lines indicated on the F.QIAC network provide dial-up access for EQIAC users to its products and services and also allow the information specialists to perform on-line searches and communicate with other IACs. Each workstation has four connections with phone lines: (1) a dedicated line to OCLC (Online Computer Library Center for Interlibrary Loan service); (2) a line for a modem to access online

\footnotetext{
'TIC has an extensive collection of more than 36,000 volumes of periodicals, 110,000 technical reports, 150,000 military and commercial standards and specifications, and 535 periodical subscriptions. In addition, TIC has on-line access to over 1,000 data bases and manages technology information for sonic boom research, privatization, hazardous waste minimization, and rapid runway repair. Computing facilities at AFCESA include: (1) three Wang VS minicomputers (series 5000, 7000, and 8000) and a CDC Cyber computer (series 830); (2.) four Defense Data Network connections to each of these four computers via the Air Force (AF) concentrator; and (3) a local area network limited within the computer room. These resources are shared among other AF installations and federal agencies mostly by means of dial-up modems.
} 


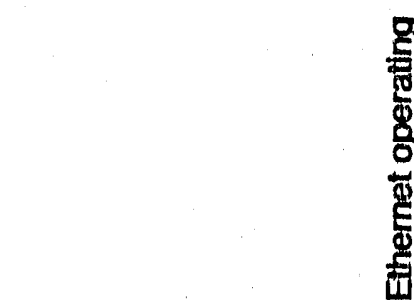

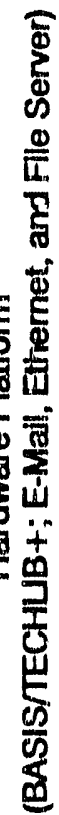
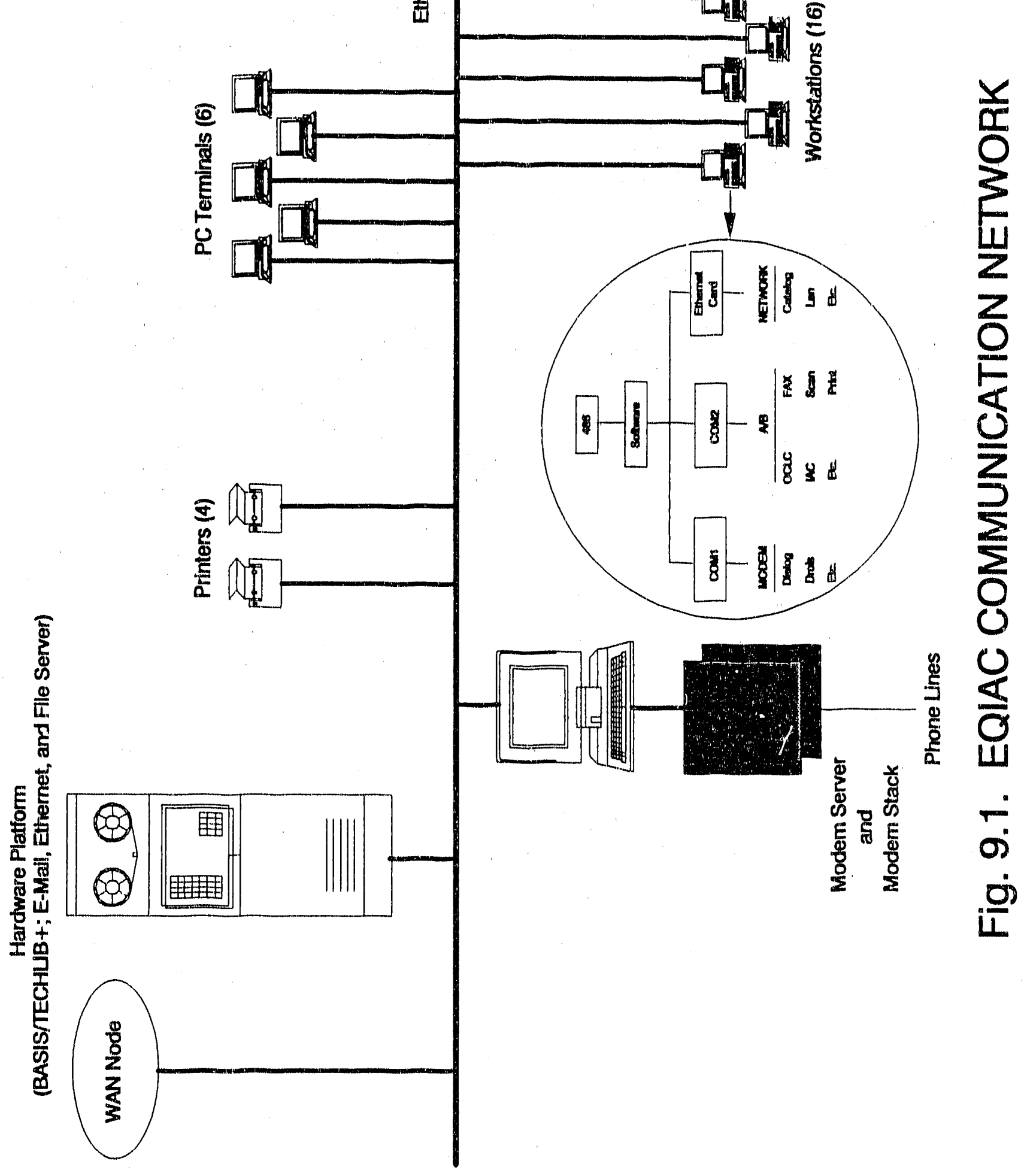
data bases, IACs, and full-text information vendors; (3) a line used by the facsimile machine; and (4) a line for the telephone. Full-text files may be downloaded immediately while books and photocopies (or facsimiles of articles and reports) may be scanned into a data base when they arrive. The Wide Area Network connection [e.g., Defense Data Network (DDN) and Internet] to the LAN improves communication for the information specialists and the Technical Analysts with DoD and other federal IACs and for EQIAC users worldwide. The Internet connection, for example, will facilitate sharing of information from the DOE, since Energy Sciences Network (connected to several super computers) of its Office of Energy Research is connected to the Internet. In the future, all federal agencies involved in remediation activities will most likely be connected to the Internet to facilitate better sharing of information.

The authorized users access EQLAC products and services by communicating to the LAN through either direct dial-ups using modems or the DDN. The users' access to EQIAC is limited to the EQIAC bulletin board, allowing access to EQIAC bulletins, information about the services, and listings of its products. EQIAC services may be requested and transmitted electronically, but users do not have access to EQIAC data bases and archives.

\subsection{INFORMATION SOURCES}

Appendices A and B provide a preliminary list of IACs and on-line data bases useful for EQIAC. In addition, numerous federally supported data bases and information systems ${ }^{2}$ in the environmental quality area are currently available. The list of on-line data bases indicated in Appendix B does not include the names of generic data bases (e.g., DTIC/DROLS, NASA/RECON, DOE/ITIS, BRS, DIALOG, ORBIT, and STN etc.), those currently subscribed by the TIC. These generic data bases provide basic useful information to EQIAC, and the existing site license will allow its usage by payment for the connect time charges. However, it will be necessary to modify the existing contractual arrangements through the Library of Congress FEDLINK for on-line services provided by the TIC to include additional on-line data bases necessary for EQIAC. Also, a separate FEDLINK and National Technical Information Service deposit account (other than the existing TIC account) needs to be established to pay charges for on-line access and use of the federal IACs and data bases by EQIAC. The basic use of DoD IACs and most federal data bases and information systems is free; however, for special requests and services, "Air Force: Form 9" (Request for Purchase) is completed to reimburse for the charges.

${ }^{2}$ (1) Accessing Federal Databases for Contaminated Site Clean-Up Technologies, EPA/540/8-91/008, prepared by the Member Agencies of the Federal Remediation Technologies Roundtable, May 1991; and (2) Inventory of Unclassified Technical Databases and Information Systems Sponsored by the Office of Technology Development and Other Organizations, memorandum from Art Kubo, BDM International, Inc., Germantown, MD 20874. April 1991. 


\section{PROCEDURES}

\subsection{REVISIONS AND UPDATES OF PROCEDURES}

The Director has primary responsibility for preparation of revisions and updates to the Operating Procedures Handbook. Proposed revisions are coordinated with the Senior Analyst (Analytical Services) and Senior Information Specialist (Information Services). Approval authority rests with the EQIAC Director.

\subsection{BUDGETING AND FISCAL، PLANNING}

An annual budget request to the Program Manager is prepared by the Director, with input from the Senior Analyst (Analytical Services) and Senior Information Specialist (Information Services). Multi-year projections of personnel, equipment, and supplies are submitted in support of the annual budget request. The Program Manager is responsible for integration of the individual requests into the overall EQIAC budget for submission to higher levels. The Director provides significant input to the Program Manager in the budget process.

\subsection{PER.3ONNEL}

Annual evaluations of personnel performance are prepared by the Director, Senior Analyst (Analytical Services), and Senior Information Specialist (Information Services) for those personnel under their direct supervision. Annual evaluations of the Section Heads (Senior Analyst, Senior Information Specialist) and of the personriel of the Office of the Director are prepared by the Director. Annual evaluations of the Director are prepared by the Program Manager.

\subsection{USER INQUIRY FOR SCIENTIFICTTECHNICAL SERVICES}

\subsubsection{User Inquiry Records}

Requests by authorized users for Scientific/Technical Services are received by the individual Information Specialists and recorded on the EQIAC User Inquiry Record form (Appendix C) and in the EQIAC User Inquiry Log (Appendix C). Assignment of the Information Services staff to the request is the responsibility of the Senior Information Specialist. Acknowledgement of the request and the response to the request is the responsibility of the Information Specialist assigned to the request.

Referral of user requests to the appropriate personnel (Technical Analysts as well as Information Specialists) is the responsibility of the Senior Information Specialist based on knowledge of the skills and experience of the entire EQIAC staff. This is particularly important for servicing first-time users of EQIAC who are not familiar with individual Technical Analysts. The Senior Information Specialist signs the User Inquiry Record to authorize the preparation of a response. 
The Senior Information Specialist also prepares and signs the cover letter transmitting the response to the authorized user and makes the entry in the User Inquiry Log.

\subsubsection{Quality Control of User Inquiry Responses}

Quality control of the responses to user requests is the responsibility of the Senior Analyst. This quality control, at a minimum, requires a quarterly report from the Senior Information Specialist to the Director of EQIAC on the timeliness of the responses to the user requests as well as a quarterly survey of the users by the Program Manager to assess user satisfaction with the quality and timeliness of the responses.

\subsubsection{Charges for Scientific/Technical Services}

No charge for Scientific/Technical services is made to authorized EQIAC users. When a request is made for EQIAC scientific/technical services from a non-authorized user, the Senior Information Specialist confers with the Director on whether to honor the request with complimentary service or to require the establishment of a formal support agreement with the requestor's organization. This decision rests with the Program Manager and is based on the magnitude of the effort required to satisfy the request as well as the nature of the requesting organization. The Program Manager signs the User Inquiry Record to indicate approval of complimentary service.

\subsubsection{Internal Requests for Scientific/Technical Services}

The support to Analytical Services by Information Services is planned jointly by the Senior Analyst and the Senior Information Specialist. A direct communication of information needs is encouraged between incividual Technical Analysts and individual Information Specialists. The Senior Information Specialist is responsible for ensuring that adequate cross-training exists among the Information Specialists, such that continuity of information support services is provided to Analytical Services at all times.

\subsection{USER REQUESTS FOR PLANNING/PROGRAMMATIC SERVICES}

Requests by authorized users for Planning/Programmatic Services are received by the individual Technical Analysts and recorded on the EQIAC Planning/Programmatic Service Request Record form (Appendix C) and are forwarded to the Senior Technical Analyst for preparation of an acknowledgement letter and entry into the Planning/Programmatic Services Request Log (Appendix C).

Assignment of Analytical Services staff to the request is the responsibility of the Senior Analyst. When a request for planning/programmatic services is within the planned resources of the Analytical Services Section, the Senior Analyst signs the request record authorizing performance of the service. The Senior Analyst also prepares and signs the cover letter transmitting the response to the authorized user and makes the entry in the Planning/Programmatic Request Log. 
When a request cannot be satisfied within planned resources, the Senior Analyst confers with the Director and the Program Manager to inform the requestor and to recommend reallocation of resources to satisfy the request. The Senior Analyst is responsible for ensuring that adequate crosstraining exists among the Technical Analysts, such that continuity of performance against planned commitments to EQIAC users is maintained at all times.

\subsubsection{Quality Control of Planning/Programmatic Services}

Quality control of the products of Planning/Programmatic Services is the responsibility of the Senior Analyst. The quality control, at a minimum, requires a quarterly report from the Senior Analyst to the Director of EQIAC on the timeliness of the delivery of analytical services and a quarterly survey of the users by the Program Manager to assess user satisfaction with the quality and timeliness of the responses.

\subsubsection{Charges for Planning/Programmatic Services}

No charge for planning/programmatic services is made to authorized EQIAC users. When a request requires an increase in the current allocation for planning/programmatic resources, the Senior Analyst, in conference with the Director and the Program Manager, will notify the requestor and propose appropriate adjustments in support from the requesting organization. The Director prepares the proposal with the authorization of the Program Manager and the contracting official.

When a request is made for EQIAC analytical services from a non-authorized user, the Senior Analyst confers with the Director on whether to honor the request with complimentary service or to require the establishment of a formal support agreement with the requestor's organization. The decision to provide complimentary service rests with the Program Manager and is based on the magnitude of the effort required to satisfy the request, as well as the nature of the requestor's organization.

The Program Manager and contracting official must approve all quotations prepared by the Director to establish new support agreements with non-authorized users.

\subsection{TECHNOLOGY/INFORMATION TRANSFER SERVICES}

\subsubsection{Scheduling of Technology/Information Transfer Services}

The EQIAC Update (Newsletter) is published quarterly by the Information Services staff under the direction of the Senior Information Specialist. A proposed schedule for publication of Handbooks and Data Books and for conducting topical reviews, training courses, and seminars is prepared annually by the Senior Information Specialist and approved by the EQIAC Director. This schedule is amended as changes occur in perceived needs of EQIAC authorized users.

\subsubsection{Charges for Technology/Information Transfer Services}

No charge is made to authorized EQIAC users for technology/information transfer services. Should an authorized user request additional technology/information transfer services requiring a 
significant increase in technology/information transfer resources, the Senior Information Specialist, in conference with the Director and the Program Manager, will notify the requestor and propose appropriate adjustments in support from the requesting organization. The Director prepares the proposal with the authorization of the Program Manager and the contracting official.

When a request is made for EQIAC technology/information transfer services from a nonauthorized user, the Senior Information Specialist confers with the Director on whether $t_{1}$ ) honor the request with complimentary service or to require the establishment of a formal support agreement with the requestor's organization. The decision to provide complimentary service rests with the Program Manager and is based on the magnitude of the effort required to satisfy the request, as well as the nature of the requestor's organization.

The Program Manager and contracting official must approve all quotations prepared by the Director to establish new support agreements with non-authorized users.

Occasionally, the Program Manager and contracting official may approve the sale of popular items such as handbooks and compendia to a range of interested parties other than EQIAC authorized users. In such cases, the sales will be on a cost-reimbursable basis, and the revenue will be applied to augment the Technology Transfer/Information Services that EQIAC offers to authorized users or to offset the costs of ongoing EQIAC services.

\subsubsection{Quality Control of Technology Transfer/Information Services}

The Director is responsible for the quality control of Technology/Information Transfer Services. Quality control, at a minimum, requires a quarterly report from the Director to the Program Manager on the timeliness of delivery of Technology/nformation Transfer Services and an annual survey by the Program Manager of the organizations who have received Technology/Information Transfer Services to determine their satisfaction with the quality and timeliness of the services received.

\subsection{SPECIAL SERVICES}

\subsubsection{Requests for Special Services}

Requests for special services that fall outside the currently planned EQIAC activities are routed to the Director. These special services may include major scientific/technical or planning/programmatic conferences, service to demonstration projects, or support to non-authorized users significantly beyond complimentary service. The Director confers with the Program Manager regarding whether or not to prepare a quotation to provide the special service. If the Program Manager authorizes the preparation of a response, the Director prepares the quotation with the assistance of the Director's staff, the Senior Analyst, and the Senior Information Specialist. The Program Manager of EQIAC must approve the quotation before submission to the requestor's organization. Acceptance of the new tasking must be authorized by the contracting official who prepares the modification to the existing contract(s) to perform the new tasking. 


\subsubsection{Quality Control of Special Services}

The Director is responsible for the quality control of performance of Special Services. Quality Control, at a minimum, requires a quarterly report from the Director to the Program Manager on the timeliness of delivery of Special Services and an annual survey by the Program Manager of the organizations who have received Special Services to determine their satisfaction with the quality and timeliness of the service received. 


\section{APPENDIX A}

A PRELIMINARY LIST OF INFORMATION ANALYSIS CENTERS THAT ARE USEFUL TO ENVIRONMENTAL QUALITY INFORMATTON ANALYSIS CENTER. 


\section{A PRELIMINARY LIST OF INFORMATION ANALYSIS CENTERS THAT ARE USEFUL TO ENVIRONMENTAL QUALITY INFORMATION ANALYSIS CENTER.}

Alternative Treatment Technical Information Center (ATTIC)

U.S. Environmental Protection Agency

Office of Research and Development

$401 \mathrm{M}$ St.

Washington, DC

Carbon Dioxide Information Analysis Center (CDIAC)

Environmental Sciences Division

Oak Ridge National Laboratory

Oak Ridge, TN 37831

Comprehensive Environmental Response, Compensation, and Liability Information System (CERCLIS)

Headquarters, U.S. Environmental Protection Agency

Washington, DC

Defense Environmental Restoration Program Management Information System (DERPMIS)

Naval Environmental Support Activity

Port Hueneme, CA

Environmental Mutagen Information Center (EMIC)

Oak Ridge National Laboratory

Oak Ridge, TN 37831

Environmental Technical Information System (ETIS)

U.S. Army Construction Engineering Research Laboratory

P.O. Box 9005

Champaign, IL 61826

Environmental Teratology Information Center (ETIC)

Oak Ridge National Laboratory

Oak Ridge, TN 37831

Environmental Restoration Remedial Actions Information System

Hazardous Waste Remedial Action Program

Martin Marietta Energy Systems, Inc.

Oak Ridge, TN 37831

Hazardous Material Management Program

Massachusetts Institute of Technology

Cambridge, MA 
Hazardous Materials Technical Information Center (HMTIC)

Richmond, VA

Interagency Testing Committee (ITC)

Headquarters

U.S. Environmental Protection Agency

Washington, DC

Installation Restoration Program Information Management System (IRPIMS)

Brooks Air Force Base

San Antonio, TX

Installation Restoration Data Information Management System (IRDIMS)

United States Toxic and Hazardous Materials Agency

Aberdeen Proving Ground, MD

National Environmental Technical Information Center (NETIC)

University of Pittsburgh Applied Research Center

Pittsburgh, PA

Pollution Prevention Information Center (PPIC)

Office of Pollution Prevention

U.S. Environmental Protection Agency

PM-222B

401 M Street SW

Washington, DC 20460

Solid and Hazardous Waste Center

University of Florida

Gainesville, FL

Supportability Investment Decision Analysis Center (SIDAC)

U.S. Air Force

Wright Research and Development Center

Wright Patterson Air Force Base, OH 45433

Toxicology Network (TOXNET)

National Library of Medicine

Washington, DC

Waste Information Network

Hazardous Waste Remedial Action Program

Martin Marietta Energy Systems, Inc.

Oak Ridge, TN 37831 
APPENDIX B

A PRELIMINARY LIST OF BIBLIOGRAPHIC DATA BASES

RELATED TO ENVIRONMENTAI TECHNOLOGIES. 


\section{A PRELIMINARY LIST OF BIBLIOGRAPHIIC DATABASES RELATED TO ENVIRONMENTAL TECHNOLOGIES.}

\section{Acid Rain}

[Availability: Data-Star (NVAR); DIMDI; ESA-IRS]

Contains about 3500 vitations, with abstracts, of worldwide literature on the sources of acid rain and its effects on the environment and human life. Covers atmospheric processes, deposition monitoring, impact on aquatic and terrestrial systems, control technologies, economic and health issues, and U.S. policy and planning. (also avallable on CD-ROM)

\section{ACIDOC}

[Avallability: Questel]

Contains approximately 8250 citations, with abstracts, of Canadian, European, and U.S. literature on all aspects, from sources to control, of acid precipitation. Covers air and atmospheric processes, environmental effects, political and socio-economic factors, and technological control.

\section{Air Toxics Report}

[Availability: Data-Star (PTBN); DIALOG]

Contains full text of Air Toxics Report, a monthly newsletter covering the Clean Air Act and National Emission Standards for Hazardous Air Pollutants and their impact on various organizations and facilities. Covers government regulations, studies, compliance, violations, and legal actions.

\section{Air/Water Pollution Report}

[Availability: Data-Star (PTBN); DIA],OG; NewsNet, Inc.]

Contains full text of Air/Water Pollution Report, a weekly newsletter covering air and water pollution, including acid rain, hazardous waste, and waste-water.

\section{Air Pollution 'Technical Information Center (APTIC)}

[Availability: DIALOG]

Contains citations, with abstracts, of literature related to the sources, effects, prevention, and control of air pollution.

\section{(BNA) Environment Daily}

[DIALOG; Executive Telecom System International, The Human Resource Information Network (ETSI/HRIN) (BNAEV); Mead Data Central, Inc. (BNAEN), West Publishing Company (BNAEND)]

Contains information on state, federal, and private-sector developments affecting pollution control and environmental protection.

BNA International Environment Report

[Availability: Mead Data Central, Inc. (INTENV)]

Contains information on pollution control activity worldwide. Covers legislation; multinational and bilateral conferences, agreements, and treatics; and social and economic issues. Includes full text of environmental-related resolutions and draft decisions adopted by the United Nations and other international organizations. 
(CERCLIS) The Data Baso of National Suporfund Sites)

[Availability: Chemloal Information Systems, Inc. (CIS)]

Contains information on over 33,06) releases of hazardous substances reported to the U.S. Environmental Protection Agency (EPA). Covers incidents of hazardous chemical spills as well as hazardous waste sites nominated or selected for cleanup under the provisions of the Superiund Amendments and Reauthorization Act of 1986 (SARA) and the Comprehensive Environmental Response Compensation, and Llability Act of 1980 (CERCLA).

Chomical Hazards Response Information Systom (CHRIS)

(Availability: CIS)

Contains information on about 1210 chemical substances for use in spill situations, includes chemical names and synonyms, molecular formula, biological and fire hazard potential, and chemical and physical properties. (also avallable on CD-ROM)

\section{Defonse Cleanup}

[Avallability: Data-Star (PTBN); DIALOG]

Contains full text of Defense Cleanup, a newsletter on the handling of defense wastes at active and inactive weapons plants and military facilities. Covers various technologies to analyze, recycle, treat, transport, and dispose of wastes.

\section{DECHEMA Environmental Technology Equipment Databank (DETEQ)}

(Availability: STN International)

Contains descriptions of about 100 types of environmental technology products from 600 companies that are available in the Federal Republic of Germany.

\section{EDF-DOC}

(Availability: ESA-IRS; Questel)

Contains over 400,000 citations, with abstracts, to the technical, economic, commercial, and social aspects of electric power generation, transportation, and sale.

Environment Libraries Automated System (ELIAS)

[Availability: CISTI, Canadian Online Enquiry Service (CAN/OLE)]

Contains about 73,000 citations to the holdings of participating Environment Canada libraries. Covers fully cataloged records for serial monograph conferences, proceedings, and technical reports.

\section{(ENREP)}

[Availability: ECHO Service]

Contains descriptions of over 50,000 research studies on the environment being conducted in European Community (EC) countries.

\section{(ENSI)}

(Availability: Asian Institute of Technology)

Contains approximately 7000 citations of the worldwide literature on environmental sanitation. Covers water supply and conservation, recycling and re-use of waste, waste treatment and disposal, and health-related aspects. 


\section{ENVIROLINE*}

(Availability: Data-Star; DIALOG; DIMDI; ESA.IRS; Life Science Network; ORBIT)

Contains about 141,000 citations (with abstracts, from 1975) to a broad range of issues and topics related to the environment and the management and use of natural resources. (also available on CDROM)

\section{Environmental Protection and Rehabilitation of Natural Resources}

[Avallability: International Centre for Scientific \& Technical Information (ICSTI)]

Contains citations, with abstracts, of the worldwide literature on environmental protection. Covers human health, wildlife protection and reserve management, natural disasters, pollution control and waste management, natural resources conservation, and soils protection.

\section{Environment Week}

[Availat:iity: Data-Star (PTBN); DIALOG; NewsNet, Inc.]

Contains full text of Environment Week, a weekly newsletter covering a wide variety of environmental issues, including acid rain, the greenhouse effect, recycling, and nuclear and hazardous waste disposal.

\section{Environmental Bibliography}

(Availability: DIALOG; Life Science Network)

Contains citations to literature on the environment, including water, air, soil, and noise pollution, solid waste management, recycling, and reduction health hazards, and urban planning. (also available on CD-ROM)

\section{Environmental Business Journal}

[Availability: Data-Star (PTBN); DIALOG]

Contains full text of Environmental Business Journal, a monthly newsletter covering business-related information on the environmental industry.

\section{Environmental Compliance Update}

(Avallability: NewsNet, Inc.)

Contains full text of Environmental Compliance Update, a newsletter covering legal, economic, and technological developments affecting compliance by business with environmental standards requirements.

\section{Facilities Index System}

(Availability: CIS)

Contains references to about 450,000 facilities and sites regulaied or tracked by the EPA because of the presence of hazardous substances. Sources include 12 EPA data bases and a number of data bases produced by state environmental agencies.

From the State Capitals: Waste Disposal and Pollution [Availability: West Publishing Co. (FTSC-WDPC)] Contains full text of From the State Capitals: Waste Disposal and Pollution, a monthly newsletter covering decisions from state legislatures, regulatory agencies, and courts on waste disposal and environmental protection. 


\section{Hazardline ${ }^{\mathrm{m}}$}

[Availability: BRS (HZBD); BRS Colleague (HZBD); Executive Telecom System International, The Human Resource Information Network (ETSI/HRIN); Life Science Network; Occupational Health Services, Inc. (OHS)]

Contains regulatory, health and precautionary data on over 78,000 hazardous chemicals.

\section{Hazardous Materials Intelligence Report}

(Availability: NewsNet, Inc.)

Contains full text of Hazardous Materials Intelligence Report, a newsletter covering legal, regulatory, technical, and commercial developments in the management of hazardous materials and wastes.

\section{Hazardous Waste News}

[Availability: Data-Star (PTBN); DIALOG; NewsNet, Inc.]

Contains full text of Hazardous Waste News, a weekly newsletter focusing on compliance and enforcement related to the regulation of hazardous wastes.

\section{Hazardous Chemicals Information and Disposal (HAZINF)}

(Availability: CIS)

Contains data on the handling and disposal of about 220 hazardous chemical substances.

Industrial Environment

(Availability: NewsNet, Inc.)

Contains full text of Industrial Environment, a monthly newsletter on business and industry products, procedures, and processes under development or in operation to improve the environment.

\section{Integrated Waste Management}

[Availability: DIALOG; Dow Jones News/Retrieval; Mead Data Central, Inc. (WENGR)]

Contains full text of Integrated Waste Management, a newsletter covering trends and developments in the worldwide conversion of agricultural, industrial, municipal, and solid wastes to energy forms.

\section{National Environunental Data Referral Service}

[Availability: BRS (NEDS); BRS/After Dark (NEDS); BRS Colleague (NEDS)]

Contains over 22,200 descriptions of sources of publicly available environmental data collected by environmental satellites, oceanographic vessels, weather stations, buoys, and environmental observers.

\section{Natur}

[Availability: DAFA Data AB]

Contains approximately 21,000 citations, most with abstracts, to research reports, including descriptions of research projects, on environmental issues in Sweden.

\section{Oil and Hazardous Materials-Technical Assistance Data System (OHM-TADS)}

(Availability: CIS)

Contains data gathered from published literature on 1402 materials that have been designated oil or hazardous materials. Provides technical support for dealing with potential or actual dangers resulting from the discharge of oil or hazardous substances. (also available on CD-ROM) 
On-Line Listings Catalog

[Availability: Northwest Industrial Waste Exchange, Inc. (NIWE)]

Contains about 400 descriptions of industrial wastes available for recycling and references to companies seeking waste products.

\section{Pollution Abstracts}

[Availability: BRS; BRS/After Dark; BRS Colleague; Data-Star (POLL); DIALOG; ESA-IRS; Life Science Network; University of Tsukuba]

Contains approximately 164,000 citations, with abstracts, to the worldwide technical and non-technical literature on pollution research, sources and controls. (also available on CD-ROM)

\section{Report on Defense Plant Wastes}

[Availability: Data-Star (PTBN); DIALOG; NewsNet, Inc.]

Contains full text of Report on Defense Plant Wastes, a newslette: covering defense industry plant wastes. Includes cleanup of contamination, funding, Congressional activities, legal actions, and health and environmental impact.

\section{Scarabee}

(Availability: Agence Nationale pour la Recuperation et l'Elimination des Dechets)

Contains about 10,000 citations, with abstracts, to the worldwide literature on waste management.

\section{Scarabee Image}

(Availability: Agence Nationale pour la Recuperation et l'Elimination des Dechets)

Contains about 10,000 references, with descriptions, to films, videotapes, slides, and other audiovisual materiais on waste management.

\section{Sludge Newsletter}

[Availability: Data-Star (PTBN); DIALOG]

Contains full text of Sludge Newsletter, a newsletter on sludge management, treatment, disposal, generation, and use.

\section{Solid Waste Report}

[Availability: Data-Star (PTBN); DIALOG; NewsNet, Inc.]

Contains full text of Solid Waste Report, a weekly newsletter covering development in the collection, transportation, and processing on nonhazardous wastes.

\section{Standards and Directories}

(Availability: CCINFOline)

Contains citations to standards, certified product directories, and other information products prepared, adopted, or endorsed by the Canadian Standards Association (CSA). (also available on CD-ROM)

\section{State Environmental Report}

[Availability: Data-Star (PTBN); DIALOG; NewsNet, Inc.]

Contains full text of State Environmental Report: Toxic Substances \& Hazardous Waste, a biweekly newsletter on hazardous wastes and toxic substances in the environment, marketplace, and workplace. 


\section{Superfund}

[Availability: Data-Star (PTBN); DIALOG; NewsNet, Inc.]

Contains full text of Superfund, a newsletter on the clean-up of hazardous wastes as required by U.S. federal and state laws. Covers cleanup programs and liability allocations.

Toxic Chemical Release Inventory (TRI)

[Availability: National Library of Medicine (NLM)]

Contains information on the annual estimated releases of over 300 toxic chemicals into the environment.

\section{Toxic Materials News}

[Availability: Data-Star (PTBN); DIALOG; NewsNet, Inc.]

Contains full text of Toxic Materials News, a weekly newsletter on EPA's Toxic Substances Control Act (TSCA).

\section{Toxics News ${ }^{\text {mm }}$}

(Availability: Capitol Records)

Contains news and information covering hazardous wastes and materials, toxic substances, and air and water quality. Includes citations, with abstracts, of relevant federal and California state legislation, EPA rulings, and other state and federal agency regulations.

\section{Waste Information Digests}

[Availability: Data-Star (PTBN); DIALOG]

Contains full text of Waste Information Digests, a monthly newsletter covering waste collection, disposal, management, and recycling.

\section{Waste Management and Resource Recovery}

(Availability: International Research \& Evaluation)

Contains citations, with abstracts, of the worldwide literature covering subjects pertinent to solid, liquid, hazardous, and nuclear waste management (water quality, toxic substances, land reclamation, and resources recovery).

\section{Wasteinfo}

(Availability: ORBIT)

Contains about 65,000 citations, mostly with abstracts, of the worldwide literature on nonradioactive waste management. 
APPENDIX C

EQIAC PROCEDURE FORMS 


\section{EQIAC SCIENTIFIC/TECHINICAL INQUIRY RECORD}

INQUIRY NUMBER: ST -

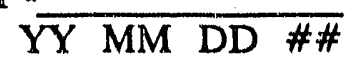

Do not write above this line. If you need more space, use a separate continuation sheet.

NAME OF INQUIRER

NAME OF INQUIRER'S ORGANIZATION

ADDRESS OF INQUIRER

\begin{tabular}{lll}
\hline PHONE NUMBER & FAX NUMBER & E-MAIL CODE
\end{tabular}

SUBJECT CODE:

(Choose one from the list below.)

B - Bibliographic Search

I - General Information

P - Publication Request

T - Technical Question (Including also Request for Technical Data, Analysis, Evaluation, and Review)

USER CODE:

(Choose one from the list below.)

DC - Defense Contractor

EC - Energy Contractor

G1 - Government Alr Force AFCESA

G2 - Government Air Force

G3 - Government Army

G3 - Government Navy

G4 - Government Other

I - Industrial Organization

U - University

\section{COMPLIMENTARY SERVICE CODE: (Choose one from the list below.)}

C1 - AFCESA Staff

C7 - Major Service Provided Free

C2 - Cooperative Program

C3 - Mutual Data Exchange

C4 - Promotional

CS - Referral

C6 - Charges Not Applicable 
SUMMARY OF INQUIRY: (Attach Correspondence, If Available.)

STAFF ASSIGNMENT:

PRIMARY RESPONSIBILITY:

CONTRIBUTORS:

LABOR REQUIREMENT:

ESTIMATE: PERSON 1

PERSON 2

PERSON 3

HOURS:

HOURS:

HOURS:

DEIIVERY STATUS:

(Choose one from the list below.)

C - Delivery Complete

O-On Schedule

D - Delay Anticipated

DELIVERY DATE:

ORIGINAL

ACTUAL

CURRENT PROJECTED

AUTHORIZATION SIGNATURES:

PRE-AUTHORIZED

(COMPLIMENTARY CODES C1-C6)

(ANY INFO SPECIALIST' OR ANALYST)

DATE

AUTHORIZED BUT MAJOR EFFORT (COMPLIMENTARY CODE C7)

(PROGRAM MANAGER)

DATE

NOT CURRENTLY AUTHORIZED 


\section{EQIAC PLANNING/PROGRAMMATIC SERVICE REQUEST RECORD}

SERVICE REQUEST NUMBER: PP -

$\overline{\mathrm{YY}} \mathrm{MM}$ DD \#\#

Do Not Wrile Above This Line. If You Need More Space, Use A Separalc Continuation Sheet.

NAME OF REQUESTER

NAME OF REQUESTER'S ORGANIZATTON

ADDRESS OF REQUTSTTR

PHONE NUMBER FAX NUMBER E-MAIL CODE

SUBJECT CODE:

R - Research and Development

(Choose One From The List Below.)

A - Acquisition

L - Logistics

F - Facility Operations

I - General Information

P - Publication Request

USER CODE: (Choose One From The List Below.)

DC - Defense Contractor

BC - Energy Contractor

G1 - Government Air Force AFCESA

G2. - Government Air Force

G3 - Government Army

G3 - Government Navy

G4 - Government Other

I - Industrial Organization

U - University

\section{COMPLIMENTARY SERVICE CODE:}

C1 - AFCESA Staff

C7 - Major Service Provided Free

(Choose One From The List Below.)

C2 - Cooperative Program

C3 - Mutual Data Exchange

C4 - Promotional

CS - Referral

C6 - Charges Not Applicable 
SUMMARY OF REQUEST: (Attach Correspondence, If Available.)

\section{STAFF ASSIGNMENT: \\ PRIMARY RESPONSIBILITY:}

CONTRIBUTORS:

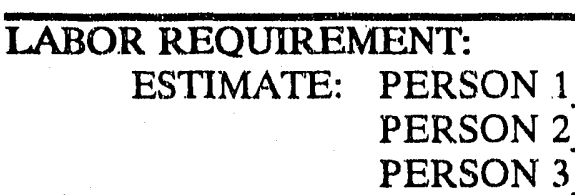

HOURS:

HOURS:

PERSON 3 HOURS:

DEIIVERY STATUS:

C - Delivery Complete

(Choose One From The List Below.)

O - On Schedule

D - Delay Anticipated

\section{DELIVERY DATE:}

ORIGINAL

CURRENT PROJECTED

ACTUAL

AUTHORIZATION SIGNATURES:

PRE-AUTHORIZED

(COMPLIMENTARY CODES C1-C6)

(ANY TECHNICAL ANALYST) DATE

AUTHORIZED BUT MAJOR EFFORT (COMPLIMENTARY CODE C7)

(PROGRAM MANAGER) DATE

NOT CURRENTLY AUTHORIZED 


\section{EQIAC SCIENTIFIC/TECHNICAL INQUIRY LOG}

$\begin{array}{llllll}\text { INQUIRY } & \text { INQUIRER } & \text { PRIMARY } & \text { DELIVERY } & \text { DELIVERY } & \text { EST TOTAL } \\ \text { NUMBER } & \text { LASTNAME } & \text { STAFFER } & \text { DATE } & \text { STATUS } & \text { LABOR HOURS }\end{array}$




\section{EQIAC PLANNING/PROGRAMMATIC REQUEST LOG}

$\begin{array}{llllll}\text { REQUEST } & \text { REQUESTER } & \text { PRIMARY } & \text { DELIVERY } & \text { DELIVERY } & \text { EST TOTAL } \\ \text { NUMBER } & \text { LASTNAME } & \text { STAFFER } & \text { DATE } & \text { STATUS } & \text { LABOR HOURS }\end{array}$


ORNL/TM-12144

\section{INTERNAL DISTTRIBUTION}

$\begin{aligned} \text { 1. } & \text { D. R. Baumgardner } \\ 2 . & \text { V. M. Bolinger } \\ 3 . & \text { B. L. Bush } \\ 4 . & \text { J. B. Cannon } \\ \text { 5. } & \text { E. D. Copenhaver } \\ 6-25 . & \text { S. Das } \\ 26 . & \text { C. R. Kerley } \\ 27 . & \text { P. S. Gillis } \\ 28 . & \text { M. A. Kuliasha } \\ 29 . & \text { D. P. Lombardl }\end{aligned}$

30, R. R. Parks

31. D. E. Reichle

32. R. B. Shelton

33. D. P. Vogt

34. T. J. Wilbanks

35. ORNL Patent Office

36. Central Research Library

37. Document Reference Section

38-40. Laboratory Records

41. Laboratory Records-RC

\section{EXTERNAL DISTRIBUTION}

42. Michael T. Barainca, Energy Information Administration, U.S. Department of Energy, EM-50, Trerion II, Washington, DC 20585

43. B. G. Buchanan, Computer Science Department, University of Pittsburgh, 206 Mineral Industries Building, Pittsburgh, PA 15260

44. J. J. Cuttica, Vice President, End Use, Research and Development, Gas Research Institute, 8600 W. Bryn Mawr Avenue, Chicago, IL 60631

45. Charles F. Holt, Ph.D., Director, Engineering and Environmental Technology, Midwest Research Institute, 425 Volker Boulevard, Kansas City, MO 64110.

46. Kathleen E. Main, Energy Information Administration, U.S. Department of Energy, EM50, Trerion II, Washington, DC 20585

47.56. Major Howard R. Meyer, Jr., Chief, R\&D Branch HQ AFCESA/RD, Building 1120, Tyndall AFB, FL 32403-8001

57. D. E. Morrison, 333 Oxford Road, East Lansing, MI 48823

58. M. Williams, Professor, Department of Economics, Northern Illinois University, DeKalb, IL 60115

59. Office of Assistant Manager for Energy Research and Development, DOE-ORO, P.O. Box 2001, Oak Ridge, TN 38831-8600

60-69. OSTI, US. Department of Energy, P.O. Box 62, Oak Ridge, TN 37831 

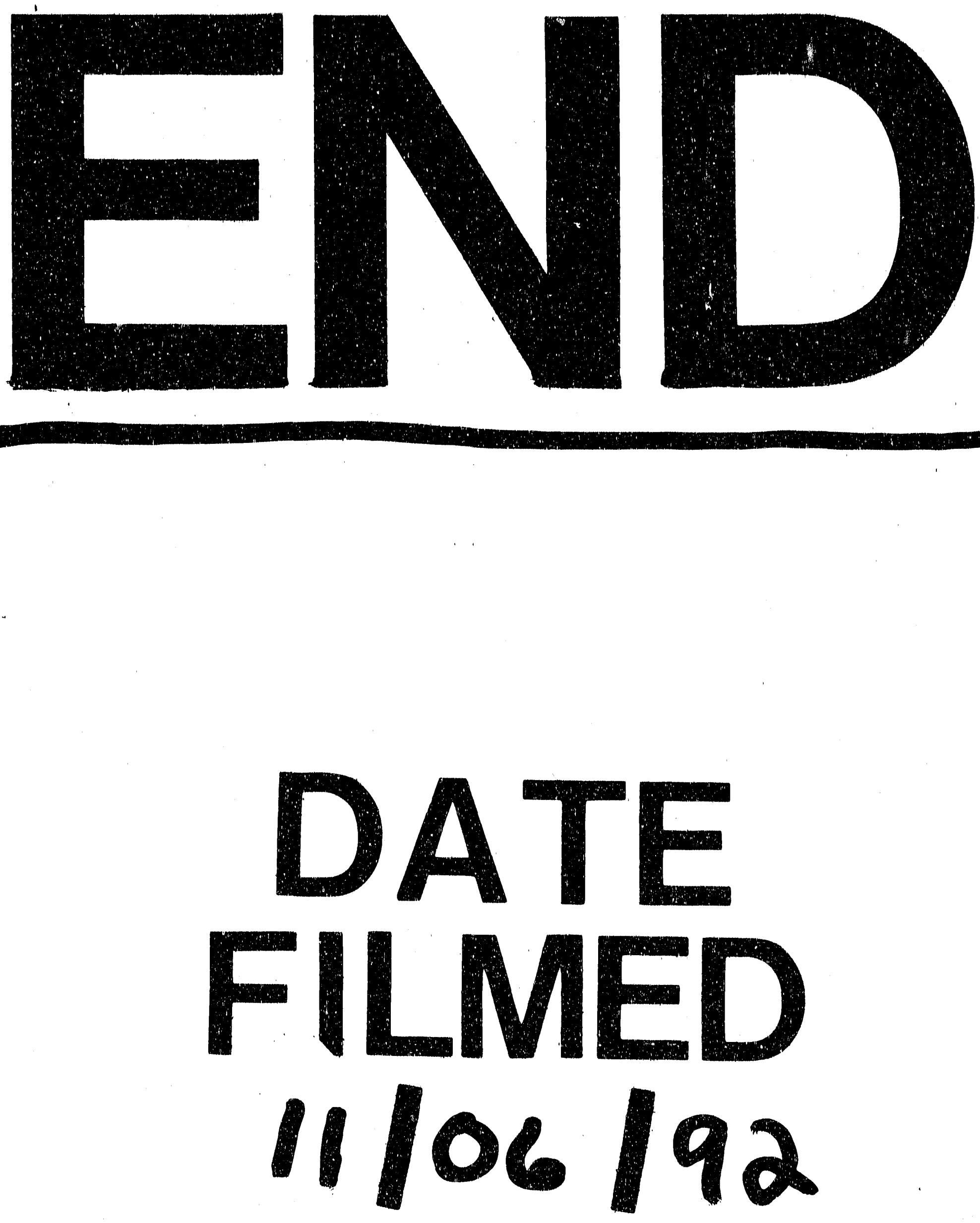


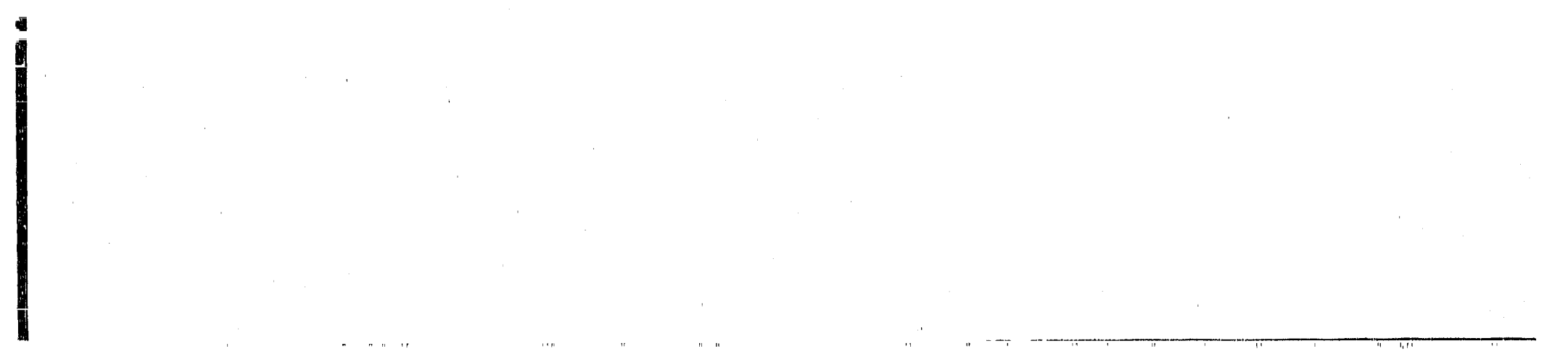

